\title{
Peningkatan Ekonomi Usaha Kecil Di Kecamatan Rumbai Pesisir Kota Pekanbaru
}

\author{
RITA WIYATI ${ }^{1}$; SRI MARYANTI²; M.THAMRIN ${ }^{3}$ \\ 1,2,3 Universitas Lancang Kuning \\ Jln. Yos Sudarso KM 08 Rumbai Telp. (0761) 52581 \\ E-mail : wiyati@gmail.com
}

\begin{abstract}
Rumbai Pesisir sub-district is an expansion of the Rumbai sub-district, consisting of six sub-districts, including: Lembah Damai Sub-District, Kelurahan Lembah Sari, Limbungan Sub-district, Limbungan Baru Village, Kelurahan Meranti Pandak Sub-District, Okura Tebing Tinggi Village. Dikamatan Rumbai Coastal livelihood of the main community is trade, fisherman and agriculture. The area is also there are many farmer group farmer groups that were formed, such as farmer group Ladang Sari and farmer group of fruit juice. Sari Buah Farmer Group and Sari Farmer Group have various business of processed food products such as onion cracker product, but the product produced during this time is not packed well so it is difficult to penetrate the wider market. The purpose of IPTEKS for this community is expected that the products produced by farmer groups can compete in the market so that no more primary products sold in the market with a relatively cheap price. With the diversification of products is expected to the emergence of new entrepreneurs who certainly can contribute to the local community. With this IPTEKS program will appear other products that have higher selling value because it has been given a more elegant packaging so attractive to consumers. Specific targets to be achieved are for partner groups and communities to be more creative and innovative to produce a variety of new products and able to increase family income and able to increase the selling value of cracker products that produce and products produced by partners can enter the supermarket with attractive packaging equipped with a permit of PPIRT (Production of Household Food Industry) for the products it produces. The methods used to achieve these objectives are to conduct training, counseling about the importance of managing the business well for each business undertaken by the partner group and create a packaging design for products that produce in order to compete and known to many people and take care of permits to enable the product to enter to a supermarket or minimarket.
\end{abstract}

Keywords: Design, Packaging, Product

Di kecamatan Rumbai Pesisir merupakan wilayah bagian dari kota Pekanbaru yang berbatasan dengan wilayah kecamatan Minas. Dikecamatan Rumbai pesisir tersebut banyak kelompok tani dibentuk, diantara kelompok tani tersebut adalah Kelompok tani sari buah dan ladang sari anggotanya merupakan ibu ibu rumah tangga , kegiatan utama kelompok tersebut membuat usaha rumahan olahan makanan kecil atau makanan ringan seperti olahan dari bahan ubi singkong, Sukun, peyek dan kripik tempe. Dikelompok mitra tersebut dalam membuat produk makanan ringannya masih sangat sederhana dalam proses pengolahannya. Begitu juga dalam kemasannya hanya dengan plastik yang dilem dengan lilin atau lampu teplok untuk merekatkannya atau diikat dengan karet.

Karena usaha yang ditekuni oleh kelompok tani tersebut masih berupa usaha rumahan yang tergolong usaha kecil sehingga dalam mengembangkan usaha tersebut sangat sulit karena selama ini kelompok tani tidak memiliki pengetahuan dalam mengelola usaha mereka sehingga bagi kelompok tani jika produk yang mereka hasilkan sudah terjual bagi mereka sudah cukup padahal untuk mengembangkan usaha agar bisa dikenal masyarakat luas tidaklah sesederhana itu. Namun hal ini sangatlah wajar karena ketidaktahuan kelompok tani dalam mengelola usahanya.Dikarenakan 
sebagian anggota kelompok mitra tingkat pendidikannyapun hanya tamatan Sekolah dasar dan Sekolah Menengah Pertama.

Usaha yang selama ini digeluti oleh sebagian besar kelompok mitra belum memiliki pengelolaan usaha yang mampu mengembangkan usaha tersebut seperti produk yang dihasilkan belum memiliki label dan bentuk kemasan dari produk yang dijual masih sangat sederhana. Namun keinginan dari pemilik usaha rumahan di Kecamatan Rumbai Pesisir adalah menginginkan produk yang mereka hasilkan dapat menembus pasar yang lebih luas lagi misalnya dapat masuk ke mini market sehingga produk tersebut dapat dikenal banyak orang dan bisa meningkatkan pendapatan keluarga.

Kami tim pengabdian kepada masyarakat berkeinginan dan bermaksud untuk memberikan pemahaman dalam mengelola usaha rumahan tersebut dengan kemasan yang lebih menarik serta pengurusan izin PIRT dan dapat dijual dengan harga yang lebih tinggi, begitu juga dapat diharapkan dijual dan dipasarkan disupermarket atau mini market terdekat.

Kelompok tani Ladang sari dan kelompok tani sari buah ini termasuk dalam usaha kecil yang merupakan sebutan dari usaha skala kecil (USK) sebagai terjemahan dari istilah small scale enterprise (SSE) yang mempunyai banyak pengertian dan konsep teoritis maupun konsep kebijakan untuk membangun usaha kecil tersebut (Anoraga dan Sudantoko,2010:244). Usaha kecil sebagai konsep mengacu kepada dua aspek yaitu pertama aspek pemasaran yaitu barang dan jasa serta memasarkan dan mencetak keuntungan dan kedua aspek pengusaha yaitu orang yang dibalik usaha atau perusahaan yang biasanya adalah pemilik pengelola sekaligus administrator dari perusahaan (Taufan, 2011;33).

Masalah yang dihadapi pengusaha kecil antara lain kurangnya pengalaman, modal terbatas,masalah lokasi, kemampuan bersaing yang kurang kuat, peralatan yang telah usang baik alat mesin atau produk, penerapan sikap yang salah, kurang mengikuti informasi dan perkembangan, dan kekeliruan pengelolaan. Memperhatikan beberapa masalah tersebut, yang sangat mendesak untuk dipecahkan masalahnya pada industri adalah kesenjangan faktor produksi dan permintaan pasar (Cahyono Adi dalam Zainur Rofiq,2010;4).

Keberhasilan sebuah usaha terutama ditentukan oleh keberanian seorang pengusaha dalam membaca situasi dan menciptakan peluang. Kemudian secara cepat mengambil keputusan dengan perhitungan yang cermat. Making money without money, atau menghasilkan uang tanpa modal adalah sebuah ungkapan yang dapat direalisasikan. Keberhasilan seseorang sangat tergantung pada kreativitas masing masing individu ( Ciputra, 2008: 19).

Kewirausahaan adalah disiplin ilmu yang mempelajari tentang nilai, kemampuan, dari prilaku seseorang dalam mengahadapi tantangan hidup untuk memperoleh peluang dengan berbagai resiko yang mungkin dihadapinya. (Sudayono; Asep Saefullah; 2011;9).

Ada beberapa definisi wirausaha menurut :

1. Pandangan Ahli Ekonomi : Wirausaha adalah orang yang mengkombinasikan faktor faktor produksi seperti sumber daya alam, tenaga kerja, material, dan peralatan lain untuk meningkatkan nilai sehingga menjadi lebih tinggi dari sebelumnya.

2. Pandangan pelaku bisnis: pelopor dalam bisnis , Inovator, penanggung resiko yang mempunyai visi, kedepan, dan memiliki keunggulan dalam prestasi dibidang usaha.

3. Pandangan Psikolog : Wirausaha adalah orang yang memiliki dorongan kekuatan dari dalam diri untuk memperoleh suatu tujuan serta suka bereksperimen untuk 
menampilkan kebebasan dirinya diluar kekuasaaan orang lain.

Nomor SP adalah Sertifikat Penyuluhan, merupakan nomor pendaftaran yang diberikan kepada pengusaha kecil dengan modal terbatas dan pengawasan diberikan oleh Dinas Kesehatan Kabupaten/Kodya, sebatas penyuluhan. Selain itu, terdapat sertifikasi berupa PIRT. Nomor PIRT ini dipergunakan untuk makanan dan minuman yang memiliki daya tahan atau keawetan diatas 7 hari. Nomor PIRT berlaku selama 5 tahun dan setelahnya dapat diperpanjang. Untuk makanan dan minuman yang daya tahannya dibawah 7 hari akan masuk golongan Layak Sehat Jasa Boga dan nomor PIRT berlaku selama 3 tahun saja.

Izin PIRT tidak dapat dikeluarkan apabila bahan yang diproduksi adalah:

1. Susu dan hasil olahannya;

2. Daging, ikan, unggas dan hasil olahannya yang memerlukan proses penyimpanan dan atau penyimpanan beku;

3. Makanan kaleng;

4. Makanan bayi;

5. Minuman beralkohol;

6. AMDK (Air Minum Dalam Kemasan);

7. Makanan / Minuman yang wajib memenuhi persyaratan SNI;

8. Makanan / Minuman yang ditetapkan oleh Badan POM.

Beberapa kiat bagi pelaku UKM

dalam menerapkan sistem manajemen, yaitu: Tabloid Peluang Usaha,2005 :

1. Tertib Administrasi. Manfaat manajemen bagi pelaku UKM untuk pengembangan usahanya sehingga di awal usaha akan lebih tertib administrasinya. Sehingga semua transaksi usaha dapat dicatat untuk direview. Kondisi yang biasa terjadi umumnya antara kepentingan bisnis dan rumah tangga tercampur, sehingga di sinilah diperlukan peran manajemen.

2. Kreativitas. Pengembangan kreativitas diperlukan, karena biasanya saat bisnis itu berdiri akan ada bisnis sejenis di lokasi yang berdekatan. Saat itulah perlu ada pengembangan kreativitas. Seperti halnya pada waralaba asing yang cukup kreatif, sehingga dengan kreativitas akan membuat produk itu bernilai jual lebih tinggi.

Fokus. Pengembangan usaha yang dilakukan disesuaikan dengan usaha yang sudah ada, sehingga meskipun ada usaha lain yang bagus perkembangannya tetap harus disesuaikan dengan kondisi usaha sebelumnya.

\section{METODE}

Dengan Memberikan pelatihan tentang pentingnya membuat kemasan produk kerupuk yang menarik agar lebih dikenal masyarakat luas dan Memberikan pengetahuan kepada kelompok mitra produk tentang pentingnya perinzinan PPIRT (Produk Pangan Industri Rumah Tangga). Adapun bentuk evaluasi pelaksanaan dari kegiatan pengabdian kepada masyarakat dilaksanakan adalah dengan memperhatikan apakah setelah kegiatan ini mitra benar-benar mempraktekan hasil dari pelatihan Namun dalam kegiatan pelatihan ini Tim PKM hanya sebatas memberikan pelatihan dan memberikan pemahaman dalam mengelola suatu usaha, perizinan dengan Depkes dan kemasan produk

\section{HASIL}

Tahap proses pelaksanaan program pengabdian kepada masyarakat yang telah dilakukan hingga pembuatan laporan akhir program IbM ini telah mencapai tahap pembuatan kerupuk bawang dan hasil produk berupa produk yang memiliki ijin PIRT, sehingga realisasinya sampai saat ini telah mencapai $100 \%$.

Pada tahap awal kegiatan IbM, Tim IbM melakukan kunjungan terhadap kedua mitra yaitu Kelompok Tani Sari Buah dan Kelompok Tani Ladang Sari, dimana kegiatan yang dilakukan oleh kedua mitra 
tersebut adalah memproduksi kerupuk yang berbahan dasar tepung tapioka dan bawang, namun produk yang dihasilkan tersebut masih memiliki kemasan yang sangat sederhana seperti tidak memiliki merk dan menggunakan kemasan plastik biasa. Untuk mengatasi masalah mitra IbM ini, kami selaku Tim IbM mencoba untuk mendesain kemasan dari produk yang dihasilkan oleh mitra dalam bentuk alumunium foil dengan memberikan merk terhadap produk yang dihasilkan

Tahapan pengurusan izin (PIRT) Tim IbM memulai dari tingkat Puskesmas Karya Wanita Rumbai Pesisir dan Puskesmas Rumbai dengan membawa ketua kelompok tani untuk pengurusan Surat Keterangan Berbadan Sehat. Tim IbM telah melakukan pengurusan surat izin PIRT ke DINKES Kota Pekanbaru. Dalam proses pengurusan Izin PIRT ada beberapa tahapan yang harus dilalui oleh pemilik usaha antara lain:

1. Membuat surat keterangan berbadan sehat pada Puskesmas setempat

2. Melakukan pengurusan ke DINAS KESEHATAN setempat dengan membawa beberapa persyaratan antara lain:

- Surat keterangan berbadan sehat dari Puskesmas

- Pas foto warna ukuran $3 \times 4$ sebanyak 5 lembar

- Foto copy KTP

- Denah/Lokasi Produksi

- Alur produksi

- Rancangan Label

3. Mengisi formulir yang telah disediakan oleh DINKES

4. Mengembalikan berkas persyaratan dan formulir pengisian ke DINKES

5. Selanjutnya fihak DINKES akan memberikan surat ke Puskesmas agar fihak Puskesmas bagian KESLING (Kesehatan Lingkungan) dapat turun ke lokasi yang dimaksud untuk melakukan kelayakan dari produk yang dihasilkan berdasarkan tempat produksi produk tersebut. Dengan memperhatikan sanitasi dan melakukan wawancara terhadap pemilik usaha.

6. Pelaporan dari fihak Puskesmas ke DINKES

7. Pemilik usaha menunggu panggilan untuk mengikuti penyuluhan sertifikasi PIRT dari pemilik usaha

Setelah tahapan di atas terpenuhi maka tim IbM menunggu pemberitahuan dari fihak DINKES untuk kegiatan sosialisasi terhadap mitra IbM, dalam kegiatan sosialisasi ini mitra akan didampingi oleh Tim IbM hal ini mengingat latar belakang pendidikan dari mitra IbM sehingga Tim IbM mengkhawatirkan sulitnya informasi yang diberikan oleh fihak DINKES diserap baik oleh mitra IbM. Dari kegiatan sosialisasi ini mitra IbM akan mendapatkan sertifikat yang dikeluarkan oleh DINKES untuk melakukan pengurusan selanjutnya yaitu syarat keluar sertifikat PIRT harus mengikuti penyuluhan yang dilaksanakan oleh DINKES Kota Pekanbaru.

Pada saat laporan kemajuan ini dibuat, sertifikat untuk mengurus PIRT sudah keluar pada tanggal 8 maret 2018, karena dalam proses pegurusannya oleh Tim Pegabdian dilakukan terlebih dahulu jauh sebelumnya.Karena ada beberapa tahapan yang harus dipenuhi oleh mitra untuk memperoleh nomor PIRT tersebut salah satunya mitra IbM harus mengikuti penyuluhan yang diadakan oleh Dinas Kesehatan Kota Pekanbaru, hal ini bertujuan untuk memberikan pengarahan terkait keamanan dari bahan pangan yang diproduksi oleh pemilik usaha sehingga produk yang dipasarkan aman bagi masyarakat.

\section{PEMBAHASAN}

Setelah proses analisis perhitungan break even point (BEP) dengan menggunakan pendekatan matematis maka 
berdasarkan data yang diterima pada waktu Tim turun lapangan kekedua kelompok tani tersebut maka dapat disampaikan untuk mencapai titik impas penjualan dalam rupiah produksi krupuk ubi kelompok tani ladang sari harus mampu menjual hasil produknya sama dengan Rp. 1.196.000 dalam setiap harinya atau lebih dari penjualan tersebut. Dan untuk mencapai unit yang dapat dijual agar krupuk ubi kelompok tani ladang sari tidak menderita kerugian, maka harus mampu menjual $15 \mathrm{Kg}$ dalam setiap harinya.

Luaran yang dicapai dalam kegiatan Pengabdian kepada Masyarakat ini adalah berupa produk yang dihasilkan dengan memiliki izin PIRT dengan kemasan alumunium foil sehingga dapat masuk ke minimarket untuk dipasarkan.

\section{SIMPULAN}

Salah satu produk yang dihasilkan oleh kelompok Tani sari buah dan ladang sari adalah kerupuk bawang. Kemasan yang dihasilkan selama ini masih sangat sederhana. Dan sekarang kelompok tani sudah melakukan pengemasan yang lebih baik dan menarik.

Produk yang dihasilkan oleh kelompok tani masih menggunakan cara tradisional seperti untuk mengemas yang awalnya menggunakan lampu teplok namun sekarang telah menggunakan Impulse Sealer dan menggunakan plastic alumunium foil dan menggunakan merk produk sehingga kemasan lebih bersih dan menarik.

Sebelum diadakannya kegiatan IbM ini kelompok tani hanya menjual produk ke konsumen yang memesan saja atau hanya dijual ke warung-warung, dengan diberikannya izin PIRT terhadap produk yang dihasilkan oleh kelompok tani maka produk yang dihasilkan dapat dijual ke mini market sehingga produk tersebut dikenal banyak orang, dengan peningkatan omset lebih dari $50 \%$ dari sebelumnya. Dari hasil kegiatan IbM ini kelompok tani mulai memahami pentingnya izin PIRT bagi produk mereka dan pentingnya manajemen usaha agar usaha merkea mampu berkembang menjadi lebih baik.
Pembinaan terhadap mitra (masyarakat dan industri kecil) sebaiknya dilakukan berkelanjutan, agar perkembangan ilmu pengetahuan dapat diaplikasikan pada masyarakat dan dapat dilakukan terus menerus dengan bahan baku yang tersedia sehingga masyarakat menjadi giat dalam meningkatkan produksi pertanian dan sektor pertanian akan terus menjadi primadona bagi masyarkat Indonesia.

Agar dalam proses pengurusan izin apapun itu di birokrasi pemerintah dapat diperoleh dengan mudah dan cepat sehingga mengurangi ketakutan dari masyarakat tentang sulitnya mengurus izin tersebut, karena jika izin dengan mudah diperoleh tentunya produk yang dihasilkan mampu bersaing dengan produk lain yang ada di pasar namun dengan mengikuti aturan dan prosedur yang berlaku.

\section{DAFTAR RUJUKAN}

Buchari Alma, 2000. Kewirausahaan, Alfabeta, Bandung.

Badraningsing dan Zainur Rofiq. 2010. Pengaduk Adonan Bakpia pada Industri Kecil Bakpia di Daerah Pinggiran. Laporan Kegiatan Program Vucer Tahun Anggaran, FT UNY.

Mulyadi Nitisusastro, 2009, Kewirausahaan \&Manajemen Usaha Kecil, penerbit Alfabeta Bandung

Philips Kloter. 2002. Strategi Pemasaran, Samelmba Empat Bandung.

Rhenald Kasali dkk. 2010, "Modul Kewirausahaan untuk Program Strata 1", Bank Mandiri dan Yayasan Rumah Perubahan: Jakarta 
Supardi, 2009, Tantangan dan Peluang Bisnis Usaha Kecil dan Menengah, UII Press Yogyakarta.

Sugiarto, 2011, Undang undang dan peraturan tentang usaha kecil dan menengah, penerbit Visi Media, Jakarta.

Thomas W. Zimmerer, Norman M. Scarborough, 2008, kewirausahaan dan manajemen usaha kecil, edisi 5 buku 2, penerbit Salemba Empat Bandung 